\title{
PENGARUH MODEL PEMBELAJARAN KOOPERATIF TERHADAP KEMAMPUAN BERPIKIR KREATIF MATEMATIS SISWA
}

\author{
NOVIYANI FLORENTINA \\ noviyani787@gmail.com \\ Program Studi Pendidikan Matematika, Fakultas Teknik, Matematika, dan IPA \\ Universitas Indraprasta PGRI \\ LEONARD \\ leonard@unindra.ac.id \\ Program Studi Pendidikan Matematika, Fakultas Teknik, Matematika, dan IPA \\ Universitas Indraprasta PGRI
}

\begin{abstract}
Abstrak. Penelitian ini dilakukan untuk memperoleh gambaran tentang pengaruh model pembelajaran kooperatif terhadap kemampuan berpikir kreatif matematis siswa.Metode penelitian yang digunakan yaitu metode eksperimen. Sampel dalam penelitian ini diambil dengan teknik simple random sampling dengan jumlah 60 orang terdiri dari 30 kelas eksperimen yang diajarkan menggunakan Jigsaw dan 30 kelas kontrol yang diajarkan menggunakan Think Pair Share (TPS). Instrumen untuk pengambilan data berupa tes uraian. Uji normalitas data menggunakan Chi-Kuadrat dan uji homogenitas menggunakan uji Fisher. Pengujian hipotesis menggunakan uji-t, menunjukkan thitung $=$ 2,286 $>\mathrm{t}_{\text {tabel }}=2,002$ dengan $\alpha=0,05$ yang menyatakan bahwa $\mathrm{H}_{0}$ ditolak, sehingga dapat di simpulkan bahwa terdapat perbedaan kemampuan berpikir kreatif matematis peserta didik yang diajarkan menggunakan model pembelajaran Jigsaw dan Think Pair Share (TPS). Dengan demikian terdapat pengaruh model pembelajaran kooperatif terhadap kemampuan berpikir kreatif matematis peserta didik.
\end{abstract}

Kata Kunci: model pembelajaran kooperatif, kemampuan berpikir kreatif matematis

\section{PENDAHULUAN}

Pendidikan merupakan bagian yang paling penting dalam kehidupan manusia. Bukan hanya bagi kehidupan manusia itu sendiri, namun pendidikan juga merupakan bagian yang paling penting dalam pembangunan nasional. Identitas suatu bangsa bergantung dengan pendidikan bangsa itu sendiri. Karena sesungguhnya pendidikan bertujuan untuk mencerdasarkan kehidupan bangsa, sebagaimana yang sesuai dengan pembukaan Undang- Undang Dasar 1945 alenia ke-4. Pendidikan memegang peranan penting dalam mempersiapkan sumber daya manusia yang berkualitas. Oleh karena itu pendidikan hendaknya dikelola, baik secara kualitas maupun kuantitas agar tujuan pendidikan dapat tercapai sesuai apa yang diharapkan bersama.

Seiring dengan perkembangan zaman dan dengan dipengaruhi oleh arus globalisasi, maka kualitas pembelajaran perlu ditingkatkan. Hal itu bertujuan untuk mampu bersaing seiring dengan perkembangan zaman serta teknologi. Hal yang utama yang harus diperhatikan yaitu dengan membangun kemampuanpeserta didik terutama kemampuan akan matematika. Matematika merupakan ilmu yang bersifat universal, matematika juga merupakan ilmu yang mendasari perkembangan teknologi modern. Pemantapan akan ilmu matematika memegang peranan yang sangat penting dimana untuk menguasai dan menciptakan teknologi. Laporan TIMSS pada tahun 2015 menunjukan bahwa penekanan pembelajaran matematika di Indonesia lebih banyak pada penugasan keterampilan dasar, namun sedikit penekanan pada penerapan kehidupan sehari-hari, berkomunikasi secara matematis ataupun bernalar secara matematis. Skor yang diperoleh 
397 dengan rangking 45 dari 48 negara yang ikut serta. Hasil tersebut dikategorikan ke dalam kelompok rendah. Hal ini menunjukkan masih kurang optimalnya pembelajaran matematika yang dilakukan disekolah.

Proses pembelajaran matematika merupakan bagian dari pendidikan di sekolah. Pada pelajaran matematika guru dianggap sebagai gudang ilmu sehingga pengajarannya akan berpusat ke guru. Guru memberi pelajaran matematika, membuktikan rumus, dan memberikan contoh soal. Sedangkan peserta didik hanya bertindak sebagai pendengar yang baik, mereka duduk dengan rapi lalu mendengarkan penjelasan dari gurunya, serta meniru cara guru dalam mengerjakan soal-soal yang telah dijelaskannya. Aktivitas tersebut yang dilakukan secara terus-menerus membuat peserta didik pasif dan cenderung kurang kreatif untuk mengutarakan ide-ide. Hal tesebut terlihat dari kemonotonan peserta didik menjawab soal-soal yang diberikan oleh gurunya. Atas dasar masalah yang terjadi diatas mengembangkan kemampuan berpikir kreatif sangatlah penting dalam pembelajaran matematika.

Kreativitas yang dimiliki setiap individu amatlah penting untuk dikembangkan guna menemukan inovasi-inovasi baru. Kemampuan bersaing yang dimiliki setiap individu sangat ditentukan oleh tingkat kreativitas yang dimilikinya. Dengan pembelajaran yang biasa dilakukan oleh guru-guru saat ini (Teacher Centered), mutu pendidikan di Indonesia dinilai masih kurang memuaskan jika di bandingkan dengan negara-negara lain. Hal ini dapat dilihat dari temuan PISA (Programme for International Student Assesment) tahun 2015, Indonesia menempati peringkat ke-62 dari 70 negara yang disurvei dengan skor rata-rata kemampuan matematika peserta didik di Indonesia yaitu 490, skor tersebut masih dibawah rata-rata internasional yaitu 496 (OECD 2015). Hal tersebut membuktikan bahwa kemampuan berpikir tingkat tinggi matematik peserta didik seperti berpikir kreatif masih rendah. Oleh karena itu, diperlukan perubahanperubahan sehingga kemampuan matematika seorang individu dapat berkembang.

Salah satu model pembelajaran yang tepat sehingga dapat digunakan untuk mengukur kamampuan peserta didik serta dapat melibatkan peserta didik secara aktif yaitu model pembelajaran kooperatif. Model pembelajaran ini menghimpun peserta didik dalam suatu kelompok yang terdiri dari beberapa orang untuk berinteraksi satu sama lain menyampaikan pendapat masing-masing. Salah satu model pembelajaran kooperatif yang dipilih disini adalah model pembelajaran kooperatif tipe Jigsaw serta Think Pair Share (TPS). Model pembelajaran Jigsaw serta Think Pair Share (TPS) merupakan salah satu model pembelajaran kooperatif dimana model pembelajaran ini menghendaki peserta didik belajar melalui kelompok yang heterogen. Namun, walaupun keduanya merupakan model pembelajaran kooperatif (kelompok) ada perbedaan yang mencolok dari kedua model pembelajaran tersebut. Perbedaan tersebut terletak pada jumlah anggota kelompok yang akan dibentuk dan tahapan pembelajaran yang berlangsung. Dalam model pembelajaran jigsaw setiap kelompok terdiri dari 4-6 orang, setiap anggota kelompok memahami dan mendalami materi tertentu kemudian perwakilan dan kelompoknya masing-masing bertemu dengan anggota-anggota dari kelompok lain yang mempelajari materi yang sama untuk kemudian berdiskusi serta memahami setiap masalah yang dijumpai sehingga perwakilan dapat memahami suatu pemahaman yang utuh. Berbeda dengan model pembelajaran Jigsaw model pembelajaran Think Pair Share (TPS) membagi kelompok menjadi dua orang dimana mereka diarahkan agar dapat menyelesikan suatu permasalahan dengan diskusi di dalam kelompok tersebut.Dalam model pembelajaran Jigsaw lebih memberikan keluasan kepada peserta didik untuk menyampaikan pendapat, gagasan, maupun ide yang dimiliki, karena dalam model pembelajaran ini terdapat jumlah anggota kelompok yang lebih banyak daripada Think Pair Share (TPS) sehingga jawaban yang dihasilkan lebih beragam. Dengan kata lain 
model pembelajaran kooperatif tipe Jigsaw ini dapat mengasah peserta didik untuk berpikir lebih kreatif, karena berpikir kreatif tidak akan datang secara tiba-tiba tanpa adanya kemampuan serta keingintahuan.

\section{TINJAUAN PUSTAKA}

\section{Kemampuan Berpikir Kreatif}

Kemampuan adalah suatu kesanggupan, kebolehan atau kecakapan untuk melakukan sesuatu. Menurut Sinaga dan Hadiati (Astuti, 2015: 71) "kemampuan sebagai suatu dasar seseorang yang dengan sendirinya berkaitan dengan pelaksanaan pekerjaan secara efektif atau sangat berhasil". Sedangkan menurut Robbins (Indrawati, 2013: 218) "kemampuan merupakan suatu aktivitas individu untuk mengerjakan berbagai tugas dalam suatu pekerjaan". Asmin (Leonard, 2013: 55) mengatakan bahwa berpikir adalah eksplorasi pengalaman yang dilakukan secara sadar dalam mencapai sesuatu tujuan. Kemampuan berpikir seseorang berbeda-beda.

Berpikir pada dasarnya dapat menghindari manusia dari kepunahan. Berpikir dapat menghasilkan berbagai macam pemikiran. Heriman (Hikmah, 2016: 482) mengatakan bahwa "berpikir kreatif adalah suatu pemikiran yang berusaha menciptakan gagasan yang baru". Sependapat dengan pendapat diatas Anika (Sari, 2016: 5), mengatakan "berpikir kreatif sebagai suatu proses yang digunakan ketika sesorang mendatangkan atau memunculkan ide baru. Ide-ide baru tersebut merupakan gabungan ide-ide sebelumnya yang belum pernah diwujudkan". Berpikir kreatif adalah aktivitas mental yang terkait dengan kepekaan terhadap suatu masalah, mempertimbangkan informasi baru dan ide-ide yang tidak biasanya dengan menggunakan strategi atau metode yang bervariasi. Fardah (Prasetyo dan Huri Suhendri, 2016: 451) menambahkan bahwa "berpikir kreatif menekankan pada aspek kelancaran (Fluency), keluwesan (Flexibility), keaslian (originality), dan keterincian (elaboration)". Sejalan dengan pendapat diatas Munandar (Husamah dan Setyaningrum, 2013: 175) mengatakan bahwa "ciri-ciri kreatif yang dapat ditunjukan dari diri seseorang meliputi kelancaran, kelenturan, atau keluwesan (fleksibelitas), dan orisinilitas dalam berpikir dan ciri-ciri ini dioperasionalkan dalam tes berpikir divergen".

Gagne (Uno, 2007: 134) mengatakan bahwa "Keterampilan berpikir kreatif (creative thinking), yakni keterampilan seseorang dalam menggunakan proses berpikirnya untuk menghasilkan ide baru, kontruktif, dan baik berdasarkan konsep-konsep, prinsipprinsip yang rasional, maupun persepsi dan intuisi". Dari beberapa teori diatas dapat disimpulkan, bahwa kemampuan berpikir kreatif adalah kemampuan berpikir yang didasarkan pada data serta informasi yang tersedia sehingga dapat menemukan kemungkinan-kemungkinan jawaban terhadap suatu masalah dari sudut pandang yang berbeda dari setiap individu.Pada umumnya sekolah memberi pengajaran dengan mengesampingkan kemampuan berpikir kreatif peserta didik. Dari berbagai materi pelajaran yang diajarkan disekolah matematika dikatakan sebagai pelajaran paling sulit oleh peserta didik. Alwi (2003: 723), mengatakan bahwa "matematika merupakan ilmu universal yang mendasari perkembangan teknologi modern, mempunyai peran penting dalam berbagai disiplin dan mengembangkan daya pikir manusia". Sedangkan Ruseffendi (Leonard dan Khomsatun, 2010: 157) mengartikan "matematika sebagai bahasa, seni dan ratunya ilmu. Matematika juga merupakan ilmu tentang struktur yang terorganisasi dengan baik serta ilmu tentang pola dan hubungan". Prasetyo dan Suhendri (2016: 451) mengatakan bahwa "kemampuan berpikir kreatif matematis merupakan kemampuan peserta didik dalam memahami dan menyelesaikan masalah dalam matematika dengan strategi dan cara yang bervariasi". Kemampuan berpikir kreatif matematis antara individu yang satu dengan yang lain berbeda-beda. Sedangkan menurut Suwarti (Sari, 2015: 94) 
mengatakan bahwa "kemampuan berpikir kreatif matematis adalah kemampuan siswa dalam memahami dan menyelesaikan suatu masalah dalam matematika dengan strategi serta cara yang bervariasi (divergen) sehingga proses berpikir kreatifnya dapat digunakan untuk proses pemecahan masalah matematika siswa secara langsung dengan tepat dan cepat".

Dari teori diatas dapat disimpulkan, bahwa kemampuan berpikir kreatif matematis adalah kemampuan berpikir yang didasarkan pada data serta informasi yang tersedia sehingga dapat menemukan kemungkinan-kemungkinan jawaban terhadap suatu masalah dari sudut pandang yang berbeda dari setiap individu dimana lebih menekankan kepada ketepatgunaan jawaban serta keragaman jawaban. Hal ini berarti kemampuan berpikir kreatif perlu dimiliki oleh setiap orang.

\section{Model Pembelajaran Kooperatif}

Model pembelajaran perlu dipahami serta diperhatikan oleh guru agar dapat melaksanakan kegiatan belajar mengajar sesuai dengan yang diinginkan. Dalam penerapannya, model pembelajaran harus disesuaikan dengan kebutuhan peserta didik itu sendiri agar apa yang disampaikan dapat diterima oleh peserta didik dengan mudahnya. Joice dan Weil (Isjoni, 2014: 50) mengatakan bahwa "model pembelajaran adalah suatu pola atau rencana yang sudah direncanakan sedemikian rupa dan digunakan untuk menyusun kurikulum, mengatur materi pelajaran, dan memberi petunjuk kepada pengajar di kelasnya". Model pembelajarana adalah suatu pola yang direncanakan serta disusun sedemikian rupa yang digunakan sebagai pedoman dan acuan dalam melaksanaan pembelajaran dikelas.Hal tersebut diperkuat oleh pendapat Ismanto (2015: 204) yang menyatakan bahwa "model pembelajaran merupakan penerapan dari suatu pendekatan, metode, dan strategi pembelajaran yang digunakan sebagai pedoman dalam pelaksanaan pembelajaran bagi seorang pengajar, sehingga dapat lebih mudah untuk mencapai tujuan belajar". Wena (2008: 189) mengatakan bahwa "pembelajaran kooperatif adalah sistem pembelajaran yang berusaha memanfaatkan teman sejawat (siswa lain) sebagai sumber belajar, disamping guru dan sumber belajar yang lainnya".

Dari beberapa teori diatas, dapat disimpulkan bahwa model pembelajaran adalah acuan/patokan yang digunakan dalam menjalankan pembelajaran di kelas untuk mempersiapkan perangkat-perangkat yang dibutuhkan dalam proses pembelajaran.

\section{Model Pembelajaran Kooperatif Tipe Jigsaw}

Jigsaw adalah model pembelajaran dimana dalam penerapannya peserta didik dibentuk dalam kelompok-kelompok, tiap kelompok terdiri atas tim ahli sesuai dengan pertanyaan yang disiapkan guru. Nur (Holisin, 2016) mengatakan bahwa "Jigsaw adalah salah satu tipe pembelajaran kooperatif yang terdiri dari beberapa orang dalam satu kelompok yang bertanggung jawab atas penguasaan materi belajar dan mampu mengajarkan bagian tersebut kepada orang lain dalam kelompoknya". Pembelajaran kooperatif tipe Jigsaw merupakan pembelajaran dengan cara mengelompokkan peserta didik yang mendorong peserta didik bertindak aktif sehingga prestasi yang diperolehnya lebih baik dari sebelumnya, hal tersebut sependapat dengan Isjoni (2014: 54) yang mengatakan bahwa "pembelajaran kooperatif Jigsaw merupakan salah satu tipe pembelajaran kooperatif yang mendorong siswa aktif dan saling membantu dalam menguasai materi pelajaran untuk mencapai prestasi yang maksimal.

Menurut Priyanto (Wena, 2008: 194) dalam penerapan pembelajaran kooperatif model jigsaw ada beberapa langkah yang harus dilaksanakan, yaitu sebagai berikut: a) Pembentukan Kelompok Asal, setiap kelompok asal terdiri dari 4-5 orang anggota dengan kemampuan yang heterogen; b) Pembelajaran pada Kelompok Asal, setiap anggota dari 
kelompok asal mempelajari submateri pelajaran yang akan menjadi keahliannya, kemudian masing-masing mengerjakan tugas secara individual; c) Pembentukan Kelompok Ahli, ketua kelompok asal membagi tugas kepada masing-masing anggotanya untuk menjadi ahli dalam satu submateri pelajaran. Kemudian masing-masing ahli submateri yang sama dari kelompok yang berlainan bergabung membentuk kelompok baru yang disebut kelompok ahli; d) Diskusi Kelompok Ahli, anggota kelompok ahli mengerjakan tugas dan saling berdiskusi tentang masalah-masalah yang menjadi tanggung jawabnya. Setiap anggota kelompok ahli belajar materi pelajaran sampai mencapai taraf merasa yakin mampu menyampaikan dan memecahkan persoalan yang menyangkut submateri pelajaran yang menjadi tanggung jawabnya; e) Diskusi Kelompok Asal (Induk), anggota kelompok ahli kembali ke kelompok asal masing-masing kemudian setiap anggota kelompok asal menjelaskan dan menjawab pertanyaan mengenai submateri pelajaran yang menjadi keahliannya kepada anggota kelompok asal yang lain. ini berlangsung secara bergilir samapi seluruh anggota kelompok asal telah mendapatkan giliran; f) Diskusi Kelas, dengan dipandu oleh guru diskusi kelas membicarakan konsepkonsep penting yang menjadi bahan perdebatan dalam diskusi kelompok ahli. Guru berusaha memperbaiki salah konsep pada siswa; g) Pemberian Kuis, kuis dikerjakan secara individu. Nilai yang diperoleh masing-masing anggota kelompok akan dijumlahkan untuk memperoleh jumlah nilai kelompok; h) Pemberian Penghargaan Kelompok, Kepada kelompok yang memperoleh jumlah nilai tertinggi diberikan penghargaan berupa piagam dan bonus nilai.

Kelebihan penggunaan model pembelajaran kooperatif tipeJigsaw sebagai berikut: a) Mengembangkan kemampuan peserta didik mengungkapkan ide atau gagasan dalam memecahkan masalah tanpa takut membuat salah; b) Dapat meningkatkan kemampuan sosial: mengembangkan rasa harga diri dan hubungan interpersonal yang positif; c) Peserta didik dapat lebih aktif dalam berbicara dan berpendapat karena mereka diberikan kesempatan untuk berdiskusi dan menjelaskan materi pada masing-masing kelompok; d) Peserta didik lebih memahami materi yang diberikan karena dipelajari lebih dalam dan sederhana dengan anggota kelompoknya.

Adapun kelemahan dalam penggunaan model pembelajaran kooperatif tipeJigsaw sebagai berikut: a) Membutuhkan banyak waktu untuk persiapan materi kecil, berdiskusi, dan mempresentasikan hasil diskusi kelompok sehingga dibutuhkan pengetahuan waktu yang lebih efektif, dan efisien; b) Peserta didik yang memiliki percaya diri, kemampuan membaca dan berpikir rendah akan mengalami kesulitan untuk menjelaskan materi apabila ditunjuk sebagai tenaga ahli; c) Keadaan kondisi kelas yang ramai, sehingga membuat siswa kurang bisa berkonsentrasi dalam menyampaikan pembelajaran yang dikuasainya.

\section{Model Pembelajaran Kooperatif Tipe Think Pair Share(TPS)}

Menurut Arends (Nasikhah dan Mujiyem Sapti: 2011), "model pembelajaran kooperatif tipe Think Pair Share merupakan suatu cara yang efektif untuk membuat variasi suasana pola diskusi kelas secara keseluruhan". Menurut Mulyatiningsih (2011: 249) langkah- langkah Think Pair Share(TPS) sebagai berikut: a) Guru menyampaikan inti materi dan kompetensi yang ingin dicapai; b) Peserta didik diminta untuk berpikir tentang materi yang disampaikan guru; c) Peserta didik diminta berpasangan dengan teman sebelahnya (satu kelompok 2 orang) dan mengutarakan presepsi masing-masing tentang apa yang telah disampaikan guru; d) Guru memimpin pleno atau diskusi kecil, tiap kelompok menemukan hasil diskusinya; e) Guru melengkapi materi yang masih belum dipahami peserta didik dan menegaskan kembali pokok permasalahan yang harus dipahami. 
Adapun Kelebihan model pembelajaran kooperatif tipe Think Pair Share (TPS) menurut Huda (Kuswati, 2012: 19) sebagai berikut: a) Meningkatkan prestasi; b) Cocok untuk tugas-tugas sederhana (tidak terlalu terstruktur); c) Masing-masing anggota memiliki lebih banyak kesempatan untuk berkonstribusi pada kelompoknya; d) Interaksi lebih mudah; e) Pembentukannya lebih cepat dan mudah.Kelemahan model pembelajaran kooperatif tipe Think Pair Share (TPS) adalah sebagai berikut: a) Jumlah kelompok yang terbentuk banyak, sehingga lebih banyak kelompok yang akan lapor dan perlu dimonitor; b) Jumlah peserta didik yang ganjil berdampak pada saat pembentukkan kelompok, karena ada satu peserta didik yang tidak memiliki pasangan; c) Lebih sedikit ide yang muncul; d) Tidak selamanya mudah bagi peserta didik untuk mengatur cara berpikir sistematik; e) Membutuhkan perhatian khusus pada ruang kelas.

\section{METODE}

Dalam melakukan penelitian ini, peneliti menggunakan penelitian metode quasi eksperimen. Peneliti secara langsung mengadakan kegiatan pembelajaran dengan menggunakan dua model pembelajaran yaitu dengan mengajar menggunakan model pembelajaran kooperatif tipe Jigsaw pada kelas eksperimen yaitu kelas VIII-B dan mengajar dengan menggunakan model pembelajaran kooperatif tipe Think Pair Share (TPS) pada kelas kontrol yaitukelas VIII-F di SMP Negeri 223 Jakarta tahun pelajaran 2016-2017 dengan pokok bahasan bangun ruang sisi datar. Pada kedua kelompok diberikan post test. Adapun desain penelitian dapat dilihat dari tabel 1.

\section{Tabel 1. Desain Penlitian}

\begin{tabular}{|c|c|c|}
\hline Kelompok & Perlakuan & Posttest \\
\hline $\begin{array}{l}(\mathrm{R}) \rightarrow \mathrm{E} \\
(\mathrm{R}) \rightarrow \mathrm{K}\end{array}$ & $\mathrm{X}$ & $\begin{array}{l}\mathrm{O}_{1} \\
\mathrm{O}_{2}\end{array}$ \\
\hline
\end{tabular}

Keterangan:

$\mathrm{R}=$ Proses pemilihan subjek secara acak.

$\mathrm{E}=$ Kelompok kelas eksperimen.

$\mathrm{K}=$ Kelompok kelas kontrol.

$\mathrm{X}=$ Perlakuan dengan menggunakan model pembelajaran kooperatif tipe Jigsaw.

$\mathrm{O}_{1}=$ hasil pengukuran satu grup yang diberi perlakuan.

$\mathrm{O}_{2}=$ hasil pengukuran satu grup yang tidak diberi perlakuan.

\section{HASIL DAN PEMBAHASAN}

\section{Hasil penelitian}

Dari hasil perhitungan, diperoleh angka-angka statistik secara deskriptif yang dinyatakan dalam tabel 2.

Tabel 2. Rekapitulasi Hasil Perhitungan Analisis Deskriptif

\begin{tabular}{cccccccc}
\hline Kelas & $\begin{array}{c}\text { Nilai } \\
\text { Terendah }\end{array}$ & $\begin{array}{c}\text { Nilai } \\
\text { Tertinggi }\end{array}$ & Mean & Modus & Median & $\begin{array}{c}\text { Simpangan } \\
\text { Baku }\end{array}$ & Varians \\
\hline Eksperimen & 93 & 60 & 76,5 & 80,5 & 77,5 & 9,882 & 97,665 \\
Kontrol & 89 & 54 & 70,9 & 73,5 & 71,5 & 9,113 & 83,421 \\
\hline
\end{tabular}

Sumber: Data diolah 
Uji normalitas dilakukan untuk mengetahui apakah data dari tiap kelompok berasal dari populasi berdistribusi normal atau tidak. Dalam penelitian ini menggunakan uji ChiKuadratdengan taraf signifikasi $5 \%$. Adapun hasil perhitungan normalitas dapat dilihat pada tabel 3 .

Tabel 3. Rekapitulasi Hasil Perhitungan Uji Normalitas

\begin{tabular}{lcccc}
\hline \multicolumn{1}{c}{ Kelas } & $\begin{array}{c}\text { Jumlah } \\
\text { Sampel }\end{array}$ & $\mathrm{X}_{\text {hitung }}^{2}$ & $\mathrm{X}_{\text {tabel }}^{2}$ & Kesimpulan \\
\hline Eksperimen & 30 & 8,020 & 11,070 & Normal \\
Kontrol & 30 & 2,352 & 11,070 & Normal \\
\hline
\end{tabular}

Sumber: Data diolah

Karena nilai $\mathrm{X}_{\text {hitung }}^{2}<\mathrm{X}_{\text {tabel, }}^{2}$ maka $\mathrm{H}_{\mathrm{o}}$ diterima yang berarti data kedua kelompok penelitian berasal dari data yang berdistribusi normal.Pengujian selanjutnya yaitu dengan melakukan uji homogenitas data. Pengujian homogenitas dapat dihitung dengan membandingkan varians terbesar dengan varians terkecil sehingga didapat $F_{\text {hitung }}=1,171$ dan nilai $\mathrm{F}_{\text {tabel }}=5,05\left(\mathrm{db}_{\text {pembilang }}=5, \mathrm{db}_{\text {penyebut }}=5\right.$ dengan $\left.\alpha=0,05\right)$. Ternyata nilai $\mathrm{F}_{\text {hitung }}$ $=1,171<\mathrm{F}_{\text {tabel }}=5,05$ maka $\mathrm{H}_{\mathrm{o}}$ diterima, sehingga dapat disimpulkan bahwa kedua kelompok data yaitu memiliki varians yang sama atau homogen.

Setelah melakukan pengujian normalitas serta homogenitas selanjutnya adalah menentukan uji hipotesis (Uji-t). Dari perhitungan tersebut didapat nilai $t_{\text {hitung }}=2,286$, sedangkan nilai $\mathrm{t}_{\text {tabel }}=2,002$ (Interpolasi) dengan $\alpha=0,05 \mathrm{dan} \mathrm{dk}=58$. Sehingga didapat nilai $t_{\text {hitung }}>t_{\text {tabel }}$ yaitu 2,286 $>2,002$ maka dapat disimpulkan bahwa $\mathrm{H}_{0}$ ditolak dan dapat ditarik kesimpulan bahwa ada perbedaan kemampuan berpikir kreatif matematis peserta didik yang diajarkan menggunakan dengan menggunakan Jigsaw lebih tinggi yang diajarkan dengan menggunakan Think Pair Share (TPS) pada pokok bahasan bangun ruang sisi datar.

\section{Pembahasan}

Berdasarkan data yang telah dianalisis dan diuji, maka diperoleh data dari kelas eksperimen yang diajarkan dengan menggunakan model pembelajaran kooperatif tipe Jigsaw maka diperoleh nilai rata-rata $(\bar{x})$ sebesar 76,5, serta modus sebesar 80,5. Sementara data yang didapatkan dari kelas kontrol yang diajarkan dengan menggunakan model pembelajaran kooperatif tipe Think Pair Share (TPS) diperoleh nilai rata-rata $(\bar{x})$ sebesar 70,9, serta modus sebesar 73,5. Sehingga dari penelitian tersebut terungkap bahwa model pembelajaran kooperatif tipe Jigsaw menyebabkan kemampuan berpikir kreatif peserta didik lebih tinggi bila dibandingkan dengan model pembelajaran kooperatif tipe Think Pair Share (TPS).

Model pembelajaran kooperatif tipe Think Pair Share (TPS) kurang efektif dalam memengaruhi kemampuan berpikir kreatif matematis peserta didik. Dalam proses pembelajaran peserta didik yang pasif akan lebih bergantung pada teman pasangannya sehingga antara peserta didik yang satu dengan yang lainnya mengalami ketergantungan dan pada model pembelajaran ini hal tersebut sesuai dengan pendapat Fadholi (2010) yang mengatakan bahwa: "siswa-siswa yang pasif, dengan metode ini mereka akan ramai dan mengganggu teman-temannnya. Tahap pair siswa yang seharusnya menyelesaikan soal dengan berdiskusi bersama pasangan satu bangku dengannya tetapi masih suka memanfaatkan kegiatan ini untuk berbicara di luar materi pelajaran, menggantungkan pada pasangan dan kurang berperan aktif dalam menemukan penyelesaian serta menanyakan jawaban dari soal tersebut padapasangan yang lain". 
Selain hal tersebut, banyaknya jumlah kelompok yang terbentuk pada saat proses pembelajaran membuat peserta didik tidak dapat memaksimalkan waktu bertanyanya kepada guru karena sang guru harus memonitor serta memerhatikan peserta didik lain. pendapatdiatas diperkuat oleh pendapat Mayasa (2013) yang menyatakan bahwa "fokus siswa yang mampu ditangani guru. Sebab dengan banyaknya siswa otomatis membuat guru harus pandai mengakomodasi semua kendala yang muncul. Selain itu, perbedaan pendapat yang muncul kadang kurang dapat diatasi". Dalam model pembelajaran kooperatif ini juga peserta didik tidak memiliki banyak keberagaman jawaban karena sedikitnya ide-ide ataupun gagasan-gagasan yang muncul dari kelompok yang terbentuk tersebut sehingga akan mengakibatkan kemampuan berpikir peserta didik tidak terasah dengan baik. Hal tersebut sejalan dengan pendapat Anika (Sari, 2016: 5), mengatakan "berpikir kreatif sebagai suatu proses yang digunakan ketika sesorang mendatangkan atau memunculkan ide baru. Ide-ide baru tersebut merupakan gabungan ide-ide sebelumnya yang belum pernah diwujudkan". Oleh karena hal tersebut, maka wajar saja model pembelajaran kooperatif tipe Think Pair Share (TPS) kurang efektif dalam meningkatkan kemampuan berpikir kreatif matematis peserta didik.

Model pembelajaran kooperatif tipe Jigsaw merupakan model pembelajaran yang memiliki kelompok awal serta kelompok akhir, dimana masing-masing anggota kelompok bertanggung jawab atas materi yang didapatnya. Setiap individu tidak hanya bertanggung jawab dalam mempelajari materi yang diberikan oleh gurunya, akan tetapi mereka juga bertanggung jawab untuk mengajari materi tersebut kepada anggota kelompoknya sehingga antara anggota kelompok yang satu dengan yang lainnya saling bertanggung jawab dan memegang peranan penting dalam suatu kelompok. Hal tersebut diperkuat oleh pendapat Lie (Pratiwi, 2009) yang mengatakan bahwa: "Jigsaw didesain untuk meningkatkan rasa tanggung jawab siswa terhadap pembelajarannya sendiri dan juga pembelajaran orang lain. Siswa tidak hanya mempelajari materi yang diberikan, tetapi mereka juga harus siap memberikan dan mengajarkan materi tersebut pada anggota yang lain. Dengandemikian, siswa akan saling tergantung satu sama lain dan harus bekerja sama secara kooperatif untuk mempelajari materi yang ditugaskan".

Pada model pembelajaran kooperatif tipe Jigsaw ini, peserta didik diarahkan untuk dapat menyelesaikan tugas secara sistematis didalam suatu kelompok. Bukan hanya diarahkan untuk menyelesaikan tugas namun pada model pembelajaran ini peserta didik diberikan kebebasan untuk saling bertukar pikiran menyampaikan ide-ide, gagasangagasan maupun pendapat mereka masing-masing, sehingga akan didapat keberagaman jawaban untuk kemudian didiskusikan kembali didalam kelompoknya yang akan bertujuan untuk melatih tingkat kepercayaan diri mereka masing-masing serta dapat menjadikan peserta didik lebih aktif. Keberagaman ide-ide yang muncul merupakan hasil dari jumlah anggota kelompok yang terbentuk, karena kelompok yang beranggotakan 4-6 orang tersebut dipandang lebih sepaham dalam menyelesaikan permasalahan suatu permasalahan dibandingkan dengan kelompok yang beranggotakan 2-4 orang. Hal tersebut sependapat dengan Pendapat tersebut diperkuat dengan hasil penelitian Slavin (Isjoni, 2014: 55) yang menyebutkan bahwa: "peserta didik yang dihimpun dalam satu kelompok yang terdiri dari 4-6 orang merupakan jumlah yang paling tepat dikarenakan kelompok yang beranggotakan 4-6 orang lebih sepaham dalam menyelesaikan suatu permasalahan dibandingkan dengan kelompok yang beranggotakan 2-4 orang”.

Model pembelajaran Jigsaw merupakan model pembelajaran yang dapat meningkatkan prestasi belajar peserta didik hal tersebut didukung oleh hasil penelitian dari Susanti (2014) yang mengatakan bahwa: "Model pembelajaran kooperatif tipe jigsaw lebih efektif digunakan daripada model pembelajaran konvensional untuk melatih siswa melakukan kerjasama yang lebih baik dengan teman dan guru, melatih siswa untuk aktif 
berdiskusi, melatih siswa agar berani menyampaikan pendapat atau pengetahuannya di depan kelas, dan melatih siswa untuk belajar menghargai orang lain yang sedang menyampaikan pendapatnya". Sependapat dengan hasil penelitian yang telah dilakukan oleh Susanti, Kholid (2009) menegaskan di dalam penelitiannya yang menyatakan bahwa "metode pembelajaran Jigsaw dapat melatih siswa untuk lebih aktif dalam berbicara dan berpendapat". Selain itu, model pembelajaran kooperatif tipe Jigsaw juga dapat meningkatnya kemampuan berpikir seseorang karena peserta didik memiliki waktu yang lebih banyak untuk memikirkan jawaban atas pertanyaan/permasalahan yang diajukan oleh guru sehingga pemerataan penguasaan materi dapat dicapai dalam waktu yang singkat. Sehingga dapat dikatakan bahwa model pembelajaran kooperatif tipe Jigsaw dapat berperan secara aktif dalam melatih kemampuan peserta didik sehingga dapat meningkatkan kemapuan berpikir serta penguasaan peserta didik akan materi pembelajaran yang diajarkan oleh gurunya.

Model pembelajaran Jigsaw merupakan model pembelajaran yang berupaya mendalami sebuah materi dengan memberikan sudut pandang yang berbeda-beda pada setiap individu sehingga peserta didik diarahkan untuk berpikir sehingga akan menghasilkan variasi-variasi jawaban. Oleh karena itu, model pembelajaran ini dapat meningkatkan kemampuan berpikir seorang individu, hal tersebut didukung oleh pendapat Alya (Septiana, 2015: 261) yang mengatakan bahwa "metode pembelajaran Jigsaw membuat pembelajaran menjadi lebih menarik dan meningkatkan kemampuan berpikir secara mendalam dan kemampuan melakukan analisis secara kritis". Model pembelajaran Jigsaw merupakan model pembelajaran yang menuntut peserta didik untuk lebih aktif dalam serta memiliki wawasan yang luas sehingga dapat menambah kualitas serta kemampuan berpikir seseorang yang akan berujung pada meningkatnya prestasi belajar. Oleh karena itu kemampuan berpikir seseorang harus ditingkatkan untuk mengembangkan kemampuan berpikir yang lainnya, hal tersebut sesuai dengan pendapat Hassoubah (Leonard, 2014: 59) mengatakan bahwa "pada kenyataannya kita ingat bahwa tiga jenis proses berpikir tersebut yaitu berpikir kreatif, menjaga, dan mengaplikasikan ilmu pengetahuan dan berpikir kritis sangat penting untuk mengembangkan kemampuan berpikir lainnya, yakni membuat keputusan, dan menyelesaikan masalah". Dalam model pembelajaran ini, mengarahkan peserta didik untuk aktif dalam memecahkan permasalahan sedangkan sang guru bertindak sebagai fasilitator yang mengarahkan serta memonitor jalannya pembelajaran sehingga pembelajaran dapat berjalan sebagai mana mestinya. Pembelajaran yang berjalan dengan baik akan menghasilkan tujuan akhir yang baik pula sesuai apa yang disepakati bersama.

Berdasarkan uraian diatas, maka dapat disimpulkan bahwa kemampuan berpikir kreatif peserta didik dapat lebih terasah serta meningkat apabila peserta didik diajarkan menggunakan model pembelajaran kooperatif tipe Jigsaw jika dibandingkan dengan model pembelajaran kooperatif tipe Think Pair Share (TPS).Karena pada dasarnya kemampuan berpikir kreatif seseorang akan tumbuh dan berkembang, apabila individu tersebut dalam belajar matematika dibimbing, diajari, dilatih, dibiasakan melakukan eksplorasi,mencoba melakukan. Sehingga mereka akan terbiasa serta terlatih dalam menyelesaikan persoalan-persoalan yang akan muncul.

\section{PENUTUP \\ Simpulan}

Berdasarkan hasil penelitian yang diperoleh, peneliti dapat menyimpulkan bahwa pelaksanaan pembelajaran matematika dengan diberikan model pembelajaran kooperatif baik tipe jigsaw maupun tipe Think Pair Share (TPS) sudah sesuai dengan aspek kemampuan berfikir kreatif matematis peserta didik. Pada proses pembelajaran kooperatif 
ini, pembelajaran dimulai dengan pemberian permasalahan yang berhubungan dengan kehidupan sehari-hari untuk didiskusikan sehingga peserta didik mampu menyelesaikan permasalahan sesuai dengan kemampuan berpikir masing-masing individu. Kemudian dari permasalahan tersebut peserta didik dapat menyampaikan ide-ide, gagasan maupun tanggapan mereka masing-masing sehingga dapat menghasilkan keberagaman jawaban sesuai langkah-langkah serta tahapan yang tepat. Peserta didik mampu bekerja sama secara aktif menghasilkan dan mengembangkan keberagaman jawaban menjadi jawaban yang tepat. Dari penyelesaian permasalahan yang telah dilakukan peserta didik mampu menyimpulkan jawaban dari permasalahan yang berhubungan dengan kehidupan seharihari sesuai dengan materi pokok yang diberikan yaitu pada bahasan bangun ruang sisi datar. Berdasarkan hasil tersebut peneliti berkesimpulan bahwa terdapat pengaruh model pembelajaran pembelajaran kooperatif terhadap kemampuan berpikir kreatif matematis peserta didik di SMP Negeri 223 Jakarta Timur. Dimana diperoleh kemampuan berpikir kreatif peserta didik yang diajar menggunakan model pembelajaran kooperatif tipe Jigsaw lebih baik daripada model pembelajaran kooperatif tipe Think Pair Share (TPS).

\section{Saran}

Berdasarkan simpulan di atas, sebagai bentuk usaha perbaikan di dalam pembelajaran untuk masa yang akan datang dan pola pikir peserta didik serta perhatian dari guru, maka saran dari penulisan adalah sebagai berikut: a) Bagi sekolah, hasil penelitian ini dapat dijadikan sebagai masukan dalam membuat kebijakan dalam usaha peningkatan kualitas pendidikan pada umumnya dan khususnya pada mata pelajaran matematika; b) Bagi guru, dalam proses pembelajaran matematika sebaiknya guru menggunakan model pembelajaran yang inovatif dan sesuai dengan gaya belajar yang dimiliki peserta didik sehingga proses pembelajaran lebih menyenangkan dan peserta didik dapat termotivasi untuk belajar matematika dan berperan aktif dalam proses pembelajaran; c) Bagi siswa, dengan penggunaan model pembelajaran kooperatif diharapkan peserta didik dapat mengikuti pembelajaran dengan aktif sehingga selalu memusatkan perhatian, serta dapat meningkatkan kreativitas, dan memiliki tanggung jawab tinggi agar mampu mencapai tujuan pembelajaran; d) Bagi peneliti, karena adanya keterbatasan dalam melaksanakan penelitian ini, maka disarankan bagi peneliti yang ingin melakukan penelitian lebih lanjut dan dapat dijadikan sebagai pembanding dalam menggunakan model pembelajaran yang lain.

\section{DAFTAR PUSTAKA}

Alwi, H. 2003. Kamus Besar Bahasa Indonesia. Jakarta: Balai Pustaka.

Astuti, S.P. 2015. Pengaruh kemampuan awal dan minat terhadap prestasi belajar fisika. Jurnal Formatif, 5(1), 68-75.

Departemen Penelitian dan Pengembangan Kemendikbud. 2011. Survey International PISA [Online]. http: //litbang.kemendikbud.go.id/index.php/-surveiinternasional-pisa. (Diakses: 19 April 2017, 11: 50).

Departemen Penelitian dan Pengembangan Kemendikbud. 2011. Survey International TIMSS [Online]. http: //litbang.kemendikbud.go.id/-index.php/surveiinternasional-timss. (Diakses: 19 April 2017, 12: 00).

Fadholi, A. 2010. Metode TPS (Think Pair Share). [Online]. http: //ariffadholi.blogspot.co.id/2010/09/metode-tps-think-pair-share.html. (Diakses: 06 Juli 2017, 23: 00).

Hikmah, N. 2016. Pengaruh problem based learning terhadap kemampuan pembelajaran berpikir kreatif. Prosiding Seminar Nasional Pendidikan Matematika, h. 481-488. Jakarta: Unindra Press. 
Holisin, I. 2016. Meningkatkan Partisipasi Siswa Kelas VII SMP Maryam Surabaya Dalam Pembelajaran Matematika Melalui Model Pembelajaran Kooperatif Tipe Jigsaw. (Diakses 15 Maret 2016).

Indrawati, F. 2013. Pengaruh kemampuan numerik dan cara belajar terhadap prestasi belajar matematika. Jurnal Formatif, 3(3), 215-223.

Isjoni. 2014. Cooperative Learning Efektifitas Pembelajaran Kelompok. Bandung: Alfabeta.

Kuswati. 2012. Ekperimentasi metode discovery dan think pair share (TPS) terhadap hasil belajar matematika siswa ditinjau dari kemampuan analogi matematis siswa. Prosiding Seminar Nasional Matematika. UNY Yogyakarta.

Leonard. 2013. Peran kemampuan berpikir lateral dan positif terhadap prestasi belajar evaluasi pendidikan. Cakrawala Pendidikan, 32(1), 54-63.

Leonard dan Supriyati, S. K. 2010. Peran belajar matematika terhadap konsistensi diri siswa (survei terhadap siswa-siswi sekolah menengah atas di Kabupaten Karawang Tahun 2010/2011). Jurnal Formatif, 1(2): 153-161.

Leonard dan Amanah, N. 2014. Pengaruh adversity quotient (aq) dan kemampuan berpikir kritis terhadap prestasi belajar matematika. Perspektif Ilmu Pendidikan, 28(1), 55-64.

Mayasa. 2013. Kelebihan KekuranganThink Pair Share (TPS). [Online]. http: //m4ya5a.blogspot.co.id/2012/10/kelebihan-kekurangan-think-pair-share.html. (Diakses 07 Juli 2017, 21: 10).

Nasikhah, Q. \& Sapti, M. 2011. Eksperimentasi model pembelajaran think pair share terhadap prestasi belajar matematika ditinjau dari kemampuan komunikasi matematika siswa kelas VII SMP sekecamatan. Prosiding dan Pendidikan Matematika. UNY Yogyakarta.

Mulyatiningsih, E. 2011. Metode Penelitian Terapan Bidang Pendidikan. Bandung: Alfabeta.

OECD. 2015. Result From PISA 2015. https: //www.oecd.org/pisa/pisa-2015-results-infocus.pdf. Diakses pada 02 Juni 2017.

Prasetyo, H. \& Suhendri, H. 2016. Pengaruh metode pembelajaran brain based learning (bbl) terhadap kemampuan berpikir kreatif matematis peserta didik. Prosiding Seminar Nasional Pendidikan Matematika Unindra, Jakarta: FTMIPA Unindra.

Sari, A. D. 2016. Pengaruh penerapan model pembelajaran kooperatif tipe think pair share (TPS) terhadap kemampuan berpikiir kreatif matematika siswa. Prosiding Seminar Nasional Pendidikan Matematika, h. 91-99. Jakarta: Unindra Press.

Sari, K. M., dkk. 2016. Pengaruh model pembelajaran think pair share terhadap kamampuan berpikir kreatif matematis siswa melalui problem posing. UPI.

Septiana, E. \& Ahdiyat, M. 2015. Pengaruh model pembelajaran kooperatif tipe STAD terhadap hasil belajar matematika. Dalam Leonard (Editor). EduReseaerch, Vol. 1, h. 251-256. Jakarta: Unindra Press.

Sugiyono. 2013. Metode Penelitian Manajemen. Bandung: Alfa Beta.

Uno, H. 2012. Belajar Dengan Pendekatan Pembelajaran Aktif, Inovatif, Lingkungan, Kreatif, Efektif, Menarik. Jakarta: Bumi Aksara.

Wena, M. 2011. Strategi Pembelajaran Inovatif Kontemporer Suatu Tinjauan Konseptual Operasional. Jakarta: PT. Bumi Aksara. 